\title{
Implementation Methods of Revert Da'wah Program in Malaysia: A Literature Review
}

Mohd. Zuhaili Kamal Basir, Nur Athiroh Masyaa'il Tan Abdullah, Fariza Md. Sham, Isdawati Ismail \& Muhammad Yasin Omar Mokhtar

To Link this Article: http://dx.doi.org/10.6007/IJARBSS/v11-i3/8967

DOI:10.6007/IJARBSS/v11-i3/8967

Received: 12 January 2021, Revised: 14 February2021, Accepted: 26 February 2021

Published Online: 15 March 2021

In-Text Citation: (Basir et al., 2021)

To Cite this Article: Basir, M. Z. K., Abdullah, N. A. M. T., Sham, F. M., Ismail, I., \& Mokhtar, M. Y. O. (2021). Implementation Methods of Revert Da'wah Program in Malaysia: A Literature Review. International Journal of Academic Research in Business and Social Sciences, 11(3), 542-555.

Copyright: @ 2021 The Author(s)

Published by Human Resource Management Academic Research Society (www.hrmars.com)

This article is published under the Creative Commons Attribution (CC BY 4.0) license. Anyone may reproduce, distribute, translate and create derivative works of this article (for both commercial and non-commercial purposes), subject to full attribution to the original publication and authors. The full terms of this license may be seen at: http://creativecommons.org/licences/by/4.0/legalcode

Vol. 11, No. 3, 2021, Pg. 542 - 555

Full Terms \& Conditions of access and use can be found at http://hrmars.com/index.php/pages/detail/publication-ethics 


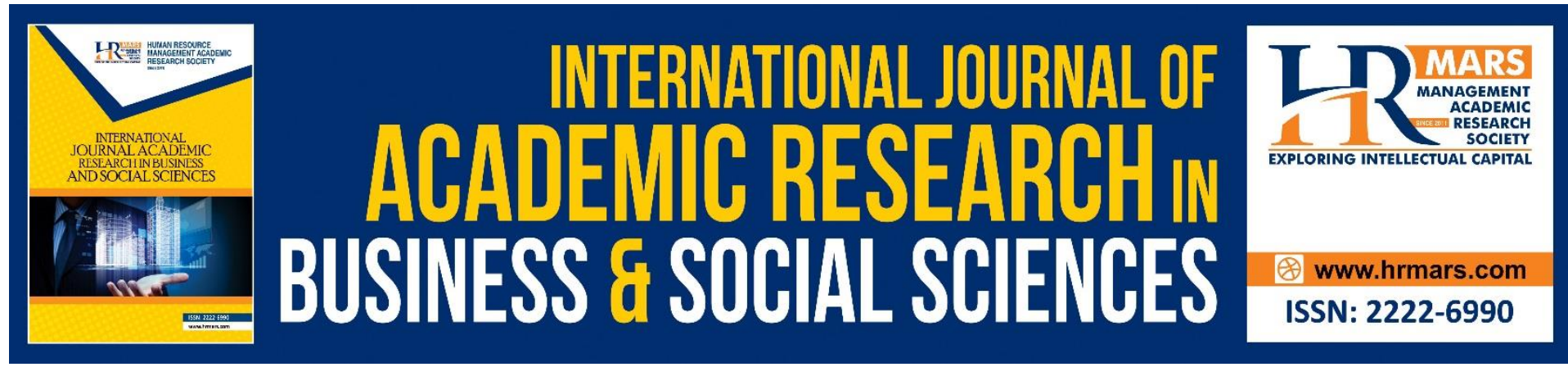

\title{
Implementation Methods of Revert Da'wah Program in Malaysia: A Literature Review
}

\author{
${ }^{1}$ Mohd. Zuhaili Kamal Basir, ${ }^{2}$ Nur Athiroh Masyaa'il Tan \\ Abdullah (Dr.), ${ }^{3}$ Fariza Md. Sham (Dr.), ${ }^{4}$ Isdawati Ismail (Dr.) \& \\ ${ }^{5}$ Muhammad Yasin Omar Mokhtar \\ ${ }^{123}$ Pusat Kajian Dakwah dan Kepimpinan, Fakulti Pengajian Islam, UKM Bangi, Selangor \\ ${ }^{1}$ Akademi Pengajian Islam Kontemporari, UiTM Sarawak Kampus Mukah, ${ }^{4}$ Politeknik Nilai, \\ Negeri Sembilan, ${ }^{5}$ Research Management Centre, Kolej Universiti Islam Melaka
}

\begin{abstract}
The deciding factors of the implementation process of a program greatly influence the output and outcome of it. It is a part of the overall input of the revert education programs that is geared towards the construction of a module framework that is constructive, comprehensive, holistic and effective. Emphasis is given on the selection of existing revert da'wah program 'uslub'(approaches) which are viewed as very conventional which do not take into consideration factors such as cross-cultural, facilities, time flexibility, knowledge competency, efficiency and mastery of the preachers and the attitude and interests of the reverts towards the content of the programs. Therefore, Government and Non-Government Da'wah Organisations have to be more considerable in selecting the methods of implementation of da'wah programs that should match the needs, problems and current development of Revert education in Malaysia. Hence, this paper will look into the development of the implementation methods of Revert Da'wah Programs in Malaysia. Qualitative method has been chosen for this study based on document analysis through academic documents, mainly journals, theses, proceedings, seminars and related newspaper cuttings. The results show that generally, the approach that has been adopted is a combination of modern and traditional approach to ensure sustainability in terms of program participation and involvements. It is hoped that this finding will become a point of reference by the program management committee to make changes and paradigm shift by adopting the latest approach to suit the passage of time. This indirectly would help elevate the standard of the Revert Education system, in line with the progress of the information system technology.
\end{abstract}

Keywords: Da'wah Approach (Uslub), Da'wah Programs, Reverts.

\section{Introduction}

Da'wah is the heart of the Islamization efforts around the world. The prophets and apostles were sent by Allah AS with the responsibilities to guide the fellow humans towards the correct tawhid and religious laws. Eventually the efforts made by the prophets and apostles were passed on to the Muslims to uphold the concept of 'Amar Ma' ruf wa Nahi Mungkar' (enjoining good and forbidding wrong) to ensure the well-being of all Muslims now and hereafter. The 
knowledge of da'wah is regarded as compulsory for a Muslim which is part of fardhu cain, obligatory acts that must be performed by each individual Muslim in which it has to be acquired, understood, internalized and practiced. This knowledge has to be acquired well so that the chosen approach matches the ' $w a q i^{\prime}$ ', the existing needs and ' mad' $^{\prime} u^{\prime}$ ', the objective of da'wah. Surah Al-Nahl (125) in the Quran has mentioned the general indicators regarding the effective da'wah strategies, which are; wisdom, good advice and debates and discussions (Salasiah, 2016). This approach is used for all including youths, women and the reverts.

One of the main groups that is the main concern of da'wah in Malaysia is the reverts. The reverts are those who have received Allah's enlightenment or guidance to learn the truth and to embrace Islam. This group has been described in the Quran (Al-Taubah, 60) as those whose hearts have been 'tamed' to accept Islam and to recite Syahadah. They are also entitled to receive zakat so that their hearts could see the beauty of Islam and therefore shall practise Islamic teachings (Amran, 1985; Nur A'thiroh et al 2009). In the initial stage, most reverts would face threats from their families, financial problems, prejudice, discrimination and stereotypes by the Muslims (Osman \& Abdul Salam, 2008). Therefore, they have to be approached properly and closely and should be given economic and psychological assistance so that they are resilient and steadfast in protecting their aqidah and beliefs in Islam (Nabilah \& Zuliza, 2014).

The approach or 'Uslub' da' wah is an approach that is used to deliver the teachings of Islam to a targeted group by persuading them to accept what is being delivered. Even though the content is based on the truth, it is still not easily accepted by the target group if the approach is not appropriate (Ab. Aziz, 2015). Therefore the suitability of the approach is vital in implementing the Revert Da'wah Programs by focusing on focused but light matters (Rokiah, 2007). The research done by Zahrah and Abdullah (2015) reveals that the reverts face problems in understanding the preaching content due to the conservative and non-creative ways of delivering it to them. Sah and Ismail (2003) found that a more interactive approach is needed to establish a positive rapport between teachers and students. This approach would affect their confidence and commitment to practise Islamic way of life.

Hence, Kasim et. al (2017) realizes the significance of mastering the right teaching method among the preachers while taking into consideration the reverts' level of knowledge and understanding towards the teaching. This is because the effectiveness of a learning process is greatly influenced by the technique and approach adopted by the preachers to ease the process of transfering ideas, knowledge, skills and experience to the reverts. The failure to choose the right approach would affect the reverts' interest, motivation, understanding, achievement and their faith towards Islam. The main concern is to ensure that the reverts do not revert to their former religion (Redzuan \& Kareelawati, 2005).

Therefore this paper aims to look at the development of the da'wah approaches that are applied by the da'wah programs in Malaysia. This research also aims to obtain general view of the latest methods that are being used by the majority of the revert da'wah NGOs in Malaysia in their efforts to care for the converts' welfare and needs.

\section{Methodology}

Qualitative method is adopted in this research paper via the analysis of related documents, mainly journal articles and proceedings. Research finding is derived in an analytical method and presented in a descriptive analysis manner. This method is best to help researchers to 
understand and identify the issues and context of the research in depth based of the secondary source of information (Munawar \& Shahizan, 2020).

Document analysis is important to ensure the level of a certain research is better and truthful. According to Syuhaimi et.al. (2017), document analysis would help a researcher get a direct input or data without having to refer to an individual or the officer in charge. Due to the valid and consistent sources, the reliability is ensured and guaranteed. This data is also useful to present and support any information and it also allows the process of comparison between old and new data. The researcher will make full use of the data and improve in terms of making a careful and detailed analysis on the primary data. This involves an academic observation which would help the process of writing a more critical paper or report.

\section{Findings}

\section{The influence of Prophet Muhammad SAW's Path (Manhaj) in The Implementation of Revert Da'wah Programs}

The da'wah carried out by the Prophet SAW was not an easy process. It required wisdom in finding the best strategies and approaches to become close and establish rapport with the target groups. The prophet had adopted six approaches in his effort to spread Islam to the early generations of Islam. The approaches were individual approach (Fardhiyyah), educating approach (Tarbiyyah), offering approach (Al-'Ardhiyyah), correspondence or representative approach (Al-Murasalah) and discussion approach (Al-Mujadalah). Eventually these approaches have been updated to suit the globalisation era and therefore widely utilize the mass media and information technology (Razaleigh, 2015).

The research carried out by Noraini Mohamad et. al. (2018) has detailed out the Prophet's approach into 12 strategies that focus on the aspect of teaching. This is because the reverts require approaches that put emphasis on the process of reading, understanding, exploring, researching and debating that would have an implication on their behaviour. The 12 strategies are gradual (tadarruj), variation (al-Tanwic wa Qudwah), exemplary examples (al-'Uswah wa Qudwah), application (al-Tatbiqi wa ${ }^{C}$ Amali), repetition (al-Taqrir wa alMurajacah), evaluation (Taqyim), dialogue (Hiwar), metaphor (Qiyas), encouragement and ultimatum (Targhib wa Tarhib), parable (al-'Amthal) and wise advice. Subsequently, Noraini Mohamad et.al. (2017) in the research has adapted Ibnu Khaldun's and Al-Ghazali's Teaching Models and also the Adult Teaching Models by Al-Rawi and Knowles to become the teaching framework for effective teaching of the reverts. The approach includes question and answer, group work, compare and contrast, wisdom approach, Targhib and Tarhib, Qudwah Hasanah and Tazkiyat al-Nafs.

In a different research, Mohamad and Majid (2017) have put an emphasis on the application of Tadarruj approach that was used by the Prophet SAW when he was in his Da'wah journey. The Prophet SAW emphasised on the aspect of awlawiyyat (priority) in his teaching method such as prioritising faith than syariah the compulsory cibadah than the necessary cibadah, becoming responsive such as being gentle and loving, executing syariah gradually according to the level of thinking of the target groups and to instill the concept of Ihsan through giving zakat to the reverts. Ghani et. al. (2017) has prioritised the approach in terms of da'wah 'bi al-hal' such as through exemplary examples, da'wah 'bi-mal' such as the giving of zakat, gifts and donations, da'wah 'bi-lisan' such as counselling and da'wah 'biqalam' such as through printed materials. This 'uslub' approach allows convenience, flexibility and fulfils their welfare so that the reverts are protected and this would strengthen their potentials to face the challenges in life. 


\section{The Implementation of Revert Da'wah Programs in Malaysia's Multi-Racial Society}

The approaches carried out by the Prophet SAW are included in the Modus Operandi of the government and non-governmental da'wah organisations in Malaysia. This combination has helped them to come up with programs and activities that are holistic, integrative and dynamic to fulfil the needs of the reverts. The analysis done towards the methods carried out by Revert Da'wah Organisations such as PERKIM, ABIM, MACMA, PIMM, USIA and HIKMAH revealed that they use the four main approaches which are 'bi-hikmah', 'bi-tarbiyyah', 'bi-alhal' and 'bi-lisan'. The programs are unique through effective da' wah communication via the mother tongue in the classes, the integration of their culture through the economic and cultural activities, sharing of experiences through dialogues and forums and the cooperation among the Revert Da'wah Organisations in charity activities (Nur A'thiroh \& Imam, 2014; Puteh et. al., 2015; Razeleigh et. al., 2015; Roslieza, 2017; Izzatil \& Nazreen, 2019; Zuhaili et. al., 2019).

The foundation of these programs reflects togetherness, justice, responsibilities and brotherhood that are encouraged in Islam in order to fulfil the rights of Muslim brotherhood, especially when they are newly introduced to Islam. This would help reduce the reverts' burden of problems that they face in upholding their faith. These are the existing approaches that are implemented in Malaysia;

\section{a) Boarding Education Model}

There are ideas and plans of creating a boarding education model to create a conducive learning environment to totally focus on learning Islam, without any distractions. Yudha and Setiyowati (2016) have carried out a study on the suitability of a revert learning centre that provides protection and temporary shelter to reduce their psychological pressure and financial burden. The study has adapted the principle of sustainable architecture that is related to the principle of economy, social and ecology that encourages a conducive and responsive learning environment for the reverts. The principle takes into account the design and space, saving electricity and water usage and to fully utilize the natural resources such as the sunlight and the quality of air that they breathe in. Such an environment would bring positive effects to the reverts who are going through the process of creating a new life that requires mental, emotional and economic stability.

The research done by Ayub et. al (2017) on the Model of Darul Hidayah Boarding Centre discovered that apart from the sufficient facilities, the program structure is constantly improved. This program has introduced beginner and advanced classes, 'halaqah' programs, mass prayer, community service activities, counselling and motivational programs and basic skill workshops. The implementation of the program focuses a lot on self-development, learning by examples, leadership, effective communication with the preachers. This environment is advantageous to the reverts because it is more Islamic and would help in developing them into progressive and dynamic Muslims. Therefore research has shown that a conducive learning environment and a comprehensive content are vital indicators for the reverts to go through the program organised by the da'wah institutions. Failure to provide these two would affect the number of participants among the reverts.

\section{b) Empowering Civilised Dialogues}

Being in a multi-racial society, the da'wah approach is constantly improved so that the reverting process of reverts is accepted well by their non-Muslim families. The study done by 
Osman Abdullah (2006) on the Chinese reverts revealed that the main obstacle comes form the racial sentiment among the family members. Hence the preachers must be able to identify the similarities that exist in terms of ethics and moral values in religious practices. According to Abdullah and Yasin (2013) the preachers themselves must set good examples as their behaviours reflect on Islam towards the non-Muslims and the reverts. These good examples will be observed and followed by the reverts and subsequently would change the negative perceptions towards Islam.

Awang and Khambali (2014) in their research found that the dialogues about life approach is the best platform to create better relationship and family bonding between the reverts and their non-Muslim families and also with the other Muslims. This bonding would prevent prejudice, stereotype and discrimination and would not stop the reverts carry on with their traditions that are not against the syarac ${ }^{c}$. Moreover the da'wah approach for instance could adopt the combination of having the Lion Dance during the Chinese New Year and iftar together with the reverts' non-Muslim family members. Besides giving exposure about the reverts' cultural background, this would also portray the beauty of Islam that does not discriminate the reverts' non-Muslim families

The research carried out by Suhid et. al (2019) proves that fiqh approach (Qawacid Fiqhiyyah) through the al-cAdah al-Muhakkamah method is able to apply the "Uruf' concept in helping the reverts to learn about Islamic rules and law gradually. This concept allows the reverts to keep their traditions as long as they are not against the Islamic teachings. This could be observed in ethnic costume, eating habits, celebrations and wedding and funeral rituals. The reverts should not be forced to follow the Malay culture to be accepted into the Malay community. For example, the Indian and Chinese reverts have the rights to retain their cultural attire as long as they do not reveal their 'caurat', eat their tradidtional food as long as it is 'halal toiyyiban' and celebrate their cultural celebrations as long as they are not superstitious. This indirectly will show that Islam is a wholesome (syumul) and flexible (murunah) religion that acknowledges the cultural differences among all races in Malaysia and it would attract the non-Muslims to learn more about the beauty of Islam.

\section{c) Neighbourhood Da'wah Concept}

This approach is more interactive and easily accepted by those in the rural areas. Based on the study done by Nasir (2015) among the aborigines at Felda Gugusan Chini Pahang, majority of the respondents have nothing against mingling and interacting with the Muslim Malays who live in the neighbouring village. In fact, they admit the kindness of the Muslim community who has taken them in as foster families, they always care for the others and always lend a helping hand and they would always be invited by the Muslims to attend their celebrations or ceremonies. The effort made by MAIDAM, Terengganu through the study carried out by Awang and Hambali (2016) reveals the openness of the non Muslim families to accept the invitation to attend da'wah programs that introduce the Chinese culture to the Muslim community and encourages good relationship among religions through respecting and understanding one another. This knowledge sharing program could also foster good neighbourhood spirit and reduce religious and racial tension that would jeopardize the peaceful life of the reverts. 
The research by Borham et. al (2017) on the success of a preacher in the in land of Sabah found that all the three approaches in Quranic da'wah which are 'hikmah, Maucizah al-Hasanah, Mujadalah' are fully adopted in creating an Islamic Social Life Model in the village. The 'Hikmah' approach was materialised by establishing a good social and psychological relationship with the non-Muslim community. The practice of visiting, serving food to visitors and giving gifts are those seen that could foster good relationship. While the 'Mau'izah' and Mujadalah' were carried out through talks and dialogues with the non-Muslim community. Moreover research has revealed that the preachers were successful through effective communications in attracting them to the mosques.

\section{d) Street Da'wah Approach}

Apart from that, societal elements are also taken into consideration in revert da'wah approach to monitor and supervise the teaching and coaching at the rural and inland areas. One of the approaches that is favoured by the reverts is visiting practice of the Street Da'wah approach. It is regarded as a macro da'wah approach that could enable an overall cultural shift in terms of education, economy, politics, family affairs and a few others (Abdul Nasir, 2013). This program is successful in inculcating visiting practice in understanding the psychological and sociological needs of the reverts who come from different ethnic and racial backgrounds. This approach also coincides with the study by Nasir and Rasit (2019) which reveals the positive acceptance by the non-Muslim community towards the Street Da'wah approach carried out by da'wah NGOs in Penang. Majority of the respondents feel more comfortable if the approach is done in a relaxed manner and by inserting the Islamic entertainment elements, decent discussion and advice, light reading handouts and the right choice of timing and situation. The welfare and entertainment elements are the new unique elements portrayed by the visiting and societal da'wah programs to attract ' $\mathrm{Mad}^{\mathrm{c}} \mathrm{u}^{\prime}$ ' that conveys messages indirectly.

According to the research carried out by Azhari and Abdullah (2018) towards Darul Azim Welfare Association in Selangor, the preachers adopted the visiting da'wah approach by establishing face to face and door to door visits to see, listen and understand directly the problems and needs of the reverts. On top of that the study by Abdullah (2013) and Ahmad and Muhaizan (2013) also found that the visiting practice has successfully established stronger and friendlier relationships through programs done by HALUAN for the overseas and local reverts. Through these programs the financial help for the reverts could be given through zakat, alms and self-support aid to ease the reverts' economic burden. Besides a complete Islamic education infrastructure such as Pusat Pembangunan Minda Insan (PPMI) in Sabah has been built and empowered to eradicate illiteracy and to elevate quranic and solah guidance among the reverts' children who are left behind in education.

\section{e) Leadership Da'wah}

A leadership da'wah approach is also regarded as an effective strategy to attract the reverts' interest in practising the value of religious life. This leadership concept includes the characters and personalities of the preachers that could be good examples to be followed by the reverts. According to the research done by Abdullah and Farhana (2015) the problem with the credibility and personality of some preachers has been the factor that shun away the reverts and has affected their attendance for the religious classes and guidance programs. The leadership aspect that has to be focused on is the 'Amar Ma'ruf wa Nahi Mungkar' that would 
develop a person into a good Muslim by following the behaviour and personality of the prophet SAW. This is in line with the suggestion by Halim Tamuri (2013) in his research whereby preachers have to equip themselves with knowledge, faith, sense of responsibilities and a good personality that is similar to the prophet's. The preachers must also bear in mind that their da'wah effort is a big responsibility that will be rewarded in the hereafter. This is where the revert training centre plays its role by organizing workshops, forums and seminars to strengthen the skills of the preachers.

The study carried out by Ibrahim and Abdullah (2019) regarding professional da'wah management that reveals that there is a significant relationship between the skill and leadership and the quality of delivery of preachers to the target group. The researchers have found that there are three important stages which are the awareness stage (marhalah astarif), the formation stage (marhalah al-takwin) and the implementation stage (marhalah altanfidh) in order to strengthen the leadership skills among the preachers. However, the researches focused only on two of the stages which are the formation stage and the implementation stage as an indicator for professional preachers that are needed to do the da'wah activities. The four identified indicators are knowledge management, leadership, communication and the commitment of the preachers to equip themselves with sufficient knowledge and a good personality to become the role model to the society. Therefore, the preachers have to be exposed to a better management that is more professional and efficient so that the position and leadership talent is acknowledged by the da'wah bodies and the society in general.

\section{f) Sports and Cultural Programs}

One of the unique features of the da'wah approach is the telematch program and the Islamic art program which is synonym with the da'wah approach towards the Peninsular Malaysia aborigine reverts. Based on the study done by Zin \& Mokhtar (2017) and Don (2017) on the da'wah programs for the aborigines, they found that both the approaches are able to attract them to the beauty of akhlak and the wholesome Islamic teachings that also celebrate joy and care for health among its believers. The programs are conducted in a warm and friendly environment with some elements of advice. Some of the telematch activities that are carried out are land rafting game, carrying ping pong ball in a spoon, walking with coconut shells, musical chair, cooking competition and many more. Meanwhile some of the cultural activities are poetry recitation, theater, video presentation and nasyid that contain religious and humanity elements. These are relevant with the aborigines' social and cultural environment that is surrounded by elements of entertainment such as singing and sports activities.

\section{g) Welfare Programs}

This approach is always practised in inland and rural areas. The study carried out by Ismail (2015) about the da'wah approach in Sana'a Yaman found that by giving gifts and financial aid, it eases the getting to know process and the delivery of advice regarding the content of Islamic teachings. In fact, some were more friendly and practise the delivery of food to the non-Muslims and this act has won their hearts to get to know more about Islam.

Yusuf et. al (2019) also observes the importance of social support especially physical support such as zakat, alms, allowance, lodging and business capital to reduce the burden and challenges faced by the reverts. This support is hoped to open their hearts to remain in Islam. 
Hence the support or help should be made known to the reverts. This is because according to the research done by Ghazali and Hamid (2013) towards the MAIS aid for the reverts in Selangor, the awareness among the reverts about the aid is satisfactory, especially about monthly aid, religious class allowance and Eid support. However, the number of recipients is still unsatisfactory because of the failure in disseminating direct information to the reverts.

\section{h) Counselling and Guidance Approach}

Counselling is an added value that has been introduced to the revert da'wah program management. The research carried out by Zafik and Dakir (2013) found that Islamic counselling for the reverts at the District Islamic Department (PAID) is put under the guidance unit as a medium to listen to their problems in general that includes aspects of teaching, finance, family and career. According to Jayos et. al (2017) the new reverts are faced with risks of emotional issues due to the internal and external pressure they have to endure as a new Muslim. Thus, the counselling unit plays an important role to help the reverts manage their emotions, feelings, way of thinking, behaviour that is hoped to be more stable. It can be seen that a combination of Islamic and multi-ethnic counselling could treat the spiritual pressure and the faith of the reverts so that they are more determined to fulfil their duties as Muslims and to also improve humanity.

Hamjah (2013) in her research has brought forward the approach by Imam Ghazali in coming up with a counselling model to overcome the sadness and frustration of the reverts. A few steps are included such as, ta'ruf method, identifying problems, finding solutions, offering alternatives to heal the souls through the Tazkiyat al-Nafs method, selecting strategies, making evaluations and ending the counselling process. it requires good relationship between the counsellor and the client. However, a comprehensive and standardised counselling model must be planned to help the reverts go through their new phase of life in a better manner. Ibrahim and Kawangit (2015) found the needs for a module to support the reverts' talent and capability development in their field of interest to be made useful in their future.

\section{i) Da'wah via the Prime Media}

Da'wah through media communication and information technology is also one of the best approaches in conveying the message of Islam to the reverts. Al-Hikmah way of communication is used to develop an effective communication approach that suits the emotional and intelligence level of the reverts. This approach takes into consideration the selection of content and the type of language used, using descriptive rather than verbal, repetitive, humour and does not touch on sensitive issues that would hurt their feelings or emotions (Zulkifli et. al 2019).

The research carried out by Awang (2015) acknowledged the role of media as an effective communication tool that could prevent negative perceptions from the reverts' nonMuslim family members, through dialogues and directly understanding Islam via audio and visual media such as a recorded quranic verse reading and religious talks that are aired on televisions and radios. The media plays an important role in a revert's life when they are going through the process of getting to know Islam and understanding Islam in the right way. Besides that, the study by Fuad and Ismail (2019) printed media and the newly introduced media are very effective in disseminating any information regarding the religious programs 
by da'wah associations such as PERKIM. They are considered effective because of the speedy dissemination of information.

Salim (2018) in her research reveals that the type of media chosen is influenced by the age and situation of the reverts. Media is vital in improving one's understanding, knowledge, interest and eagerness to revert into Islam. Back in the 90 's the popular media were televisions, radios and religious books. On the other hand, the new generations are exposed to Facebook, Instagram and a few others as their popular media. However, the role of religious books is still significant as the main medium as they have more reliable sources compared to the others.

Nevertheless, social media is seen as the leading platform to convey messages about Islam, which is easier and cheaper. Information about revert training and guidance centres such as PERKIM, MACMA, Hidayah Centre, MIRA could be obtained easily through social media. However, Dundai and Hafizah (2019) have cautioned the reverts and others about being mindful and vigilant when they are searching for religious information via the social media by making sure that the information comes from reliable and valid sources. Therefore, the influx of Islamic content in social media should be monitored and controlled so that there would be no deviation from the truth that could sway one faith.

The impact of social media has also its effects on the use of technology such as smart phones as a medium of learning for the reverts in Malaysia. Therefore, the study by Fatin Alia Phang et.al (2019) has used the M-Learning platform to create "Edu-Muallaf" application for free based on online learning. This will help for those reverts who face time and logistics limitations to attend religious classes during weekends. Through this mobile application, they could learn more about Islam at anytime and anywhere, download teaching content, finish module content at their convenience and communicate synchronously with the preachers. To the preachers, the application helps them to monitor and supervise the students' progress and to identify those who are left behind in grasping the knowledge of "fardhu ain".

The are some examples of the application for the reverts prayer guide and Al-Quran recitation. This can be seen in the research done by Praditasari et. al. (2018) who has prepared a religious teaching with the help of the use of 'Hanguel' language which is effective in Korea. The activities combine several topics such as prayer guidance, ablution activity and the reading of important surahs in the Quran and "iqra'. The interesting part is, the content comes with a Korean background and Korean language. Hence, this application has been used by the religious teachers at Itaewon Mosque, South Korea. This study has proven the effectiveness of technology applications to help the reverts obtain extra knowledge besides the lessons they receive from the lessons and courses from the mosques, Islamic Centre and Religious Guidance Centre.

\section{Conclusion}

Based on past researches, the researcher found that there are many up-to-date methods and approaches that are used for the reverts. Every approach or technique should suit their social surrounding and level of competency. The revert da'wah programs also are seen to adopt the latest pedagogy technique that is suitable with their needs and demands so that it is effective and acceptable. There is also a transformation from using the tarbiyyah approach to ' $b i$ 
hikmah' and 'bi Hal' da' wah in the welfare activities. This is further strengthen by the Boarding Model which functions as the centre to produce da'wah leaders among the reverts. The community social programs are empowered by several new approaches such as da'wah visits, street da'wah and reverts' village model that portray good neighbourhood and Islamic brotherhood. Financial Aid is also given to the reverts to help ease their financial burden. Moreover, the teaching and learning technique is further strengthen through the prime media and information technology to speed the process of disseminating knowledge about Islam to the reverts. These would attract and motivate the reverts to join the programs consistently and would bring about positive impact on their appreciation of Islam in their lives.

\section{Acknowledgement}

This research received no specific grant from any funding agency in the public, commercial or not-for-profit sectors.

\section{Corresponding Author}

Nur Athiroh Masyaa'il Tan Abdullah @ Tan Ai Pao

Pusat Kajian Dakwah dan Kepimpinan

Fakulti Pengajian Islam, UKM

Email:athiroh@ukm.edu.my

\section{References}

Abdullah, J. L. J. (2013). Pespektif NGO di Lapangan: Mendepani Cabaran Tarbiyah \& Kebajikan Mualaf di Malaysia. DIm. Siti Ruqayah Hj. Tibek et al. $\quad$ (pnyt.). Prosiding Antarabangsa Pembangunan Muallaf 2013, hlm.77-92. Shah Alam: Majlis Agama Islam Selangor.

Abdullah, M. R. T., \& Yasin, R. (2013). Pendekatan konsep Hikmah dalam Proses Bimbingan Saudara Muslim. DIm. Siti Ruqayah $\mathrm{Hj}$. Tibek et al. (pnyt.). Prosiding antarabangsa Pembangunan Muallaf 2013, hlm. 205-214. Shah Alam: Majlis Agama Islam Selangor.

Abdullah, N. A., Masyaail, T., \& Sham, F. M. (2009). Keperluan Memahami Psikologi Saudara Muslim. Jurnal Hadhari, 2: 83-97.

Awang, A. (2015). Pengaruh Media dalam Dialog Kehidupan: Perspektif Pengalaman Saudara Baru. Jurnal Komunikasi, 31: 47-60.

Azhari, N. A., \& Abdullah, N. A. M. T. (2018). Metodologi Dakwah Pertubuhan Kebajikan Darul Azim kepada Mualaf di Selangor Malaysia: Satu Kajian Awal. Jurnal At-Tahkim, 8: 1-7.

Borham, A. H., Abdullah, W. H., Rahim, M. M. M., \& Kamaruzaman, M. A. (2016). Metod dakwah Mohd Fadli Yusof dalam pengislaman suku kaum masyarakat Murut di pedalaman Sabah. Jurnal Al- Hikmah, 8: 60-80.

Don, A. G. (2017). Dakwah kepada Masyarakat Orang Asli: Pengalaman Pengislaman di Paya Sendayan, Temerloh, Pahang Darul Makmur. DIm.Abdul Ghafar Don \& Zulkiple Abd. Ghani (pnyt.). Dakwah kepada Non Muslim di Malaysia: Konsep Metode dan Pengalaman, hlm.106-113. Bangi: Penerbit UKM

Don, A. G., Mohd, A. R., Yunus, Puteh, A., \& Nasir, B. M., (2017). Cabaran Dakwah dalam Kalangan Saudara Baru di Malysia. DIm.Abdul Ghafar Don \& Zulkiple Abd. Ghani (Pnyt.). Dakwah kepada Non Muslim di Malaysia: Konsep Metode dan Pengalaman, hlm.162169. Bangi: Penerbit UKM. 
Fuad, Z., \& Ismail, N (2019). Metodologi Dakwah Pendakwah Terhadap Saudar Baru: Kajian di PERKIM, Kuala Lumpur. Persidangan Antarabangsa Tokoh Ulama Melayu Nusantara, hlm: 193-200. Shah Alam: Hotel Grand Wave.

Ghani, M., Zulkifli, A., Osman, K., Mokhtar, A. I., Puteh, A., \& Don, A. G. (2017). Penerapan fiqh awlawiyyat dalam dakwah kepada saudara baru. Jurnal Al-Hikmah, 9: 131-140.

Ghani, Z. A. (2017). Konversi Agama: Memahami Psikologi dan Komunikasi Berkesan kepada Saudara Baru. DIm. Fariza Md. Sham (pnyt.). Dakwah dan Kaunseling di Malaysia, hlm. 71-80. Bangi: Penerbit UKM.

Ghazali, A., \& Hamid, Z. A. (2013). Kajian Berkaitan Kepuasan Responden Terhadap Program Bantuan Kepada Mualaf Di Selangor. Prosiding Antarabangsa Pembangunan Muallaf 2013, hlm: 55-66. Shah Alam: Majlis Agama Islam Selangor.

Hamjah, S. H. (2016). Dakwah dan Perubahan Sosiobudaya. Bangi: Penerbit UKM.

Hamjah, A. H. (2013). Pendekatan Kaunseling dalam Menangani Emosi Mualaf. Dlm.Siti Ruqayah Hj. Tibek et al. (pnyt.). Prosiding Antarabangsa Pembangunan Muallaf 2013,hlm. 93-102. Shah Alam: Majlis Agama Islam Selangor.

Ibrahim, I. \& Abdullah, B. (2019). Pendekatan Pengurusan Kemahiran Pendakwah Profesional dalam Dakwah Kepada Masyarakat Awam. Dlm. Syahrul Fahmy et. al (pnyt.). Proceeding of the International Conference on Islamic Civilization and Technology Management. hlm. 496-506. Terengganu. Research Institute for Islamic Product and Malay Civilization (INSPIRE), UnisZA.

Ismail, A. H. (2015). Berdakwah kepada Bukan Islam: Pengalaman Saudara Kita di Sana'a Yaman. DIm. Razaleigh Muhamat@ Kawangit (pnyt.) Isu-Isu Pengurusan Saudara

Jayos, S., Ghani, F. A., Tahir, L. M., Jasmi, K. A. \& Bandar, N. F. A. (2017). Organization as Support System among Revert Clients in Malaysia. Journal of Cognitive Sciences and Human Development, 3:41-46.

Kasim, A. Y., Hamid, S. A., \& Jemali, M. (2017). Pengajaran Akidah dalam Kalangan Mualaf di Institut Dakwah Islamiyah PERKIM. Jurnal Perspektif, 1:89-100.

Kasimin, A. (1985). Saudara Baru Cina di Wilayah Persekutuan dan Selangor. Monograf FSKK. Universiti Kebangsaan Malaysia.

Mohamad, N., \& Majid, M. A. (2016). Konsep al-Tadarruj dalam Penyampaian Dakwah Saudara Baru. Abur Hamdi Usman (pnyt.). Seminar Antarabangsa Akidah, Dakwah dan Syariah (IRSYAD), hlm. 181-192. Bangi Kolej Universiti Antarabangsa

Selangor (KUIS).

Mohamad, N., Majid, M. A., \& Nasir, B. M. (2018). Pendekatan Dakwah dalam Kaedah Pengajaran kepada Muallaf. Jurnal Wardah, 19: 1-17.

Mohamad, N., Majid, M. A., \& Omar, A. N. (2017). Metodologi Pengajaran Mualaf di Institut Dakwah Islamiah PERKIM (IDIP). e-Jurnal Penyelidikan dan Inovasi, 4:215-233.

Muhamat, R.@K. (2015).Pembangunan Dakwah Kontemporari kepada Saudara Baru di Malaysia. Akses pada 3 April 2020 di https://www.researchgate.net/publication/303023907

Muhamat, R.@k., Don, A. G., \& Puteh, A. (2015). Dakwah PERKIM Pahang kepada Muallaf Orang Asli. DIm. Razaleigh Muhamat@ Kawangit (pynt.). Isu-Isu Pengurusan Saudara Muslim. hlm, 117-132. Bangi: Penerbit UKM.

Nasir, B. M. (2015). Dakwah Masyarakat Berjiran kepada Orang Asli: Kajian di Felda Gugusan Chini Pahang. DIm. Razaleigh Muhamat@ Kawangit (pnyt.). Isu-Isu Pengurusan Saudara Muslim, hlm. 17-25. Bangi: Penerbit UKM. 
Nazri, N. I. F. M., \& Ismail, N. (2019). Peranan Hidaya Centre dalam Pemantapan Akidah Golongan Muallaf di Sabah. Dlm. Azri Bhari et al. (pnyt.). Dlm. Potensi Muallaf MendepaniCabara Era Kontemporari, hlm. 157-180. Shah Alam: Institut Kajian Zakat (IKAZ) \& Akademi Pengajian Islam Kontemporari (ACIS).

Phang, F. A., Shukor, N. A., Pusppanathan, J., Halim, N. D. A., Khair, Z., Sulaiman, S., Ruskam, A., Junaidi, J., Rashid, A. H. A., \& Bachok, M. F.. (2019). Edu-Muallaf: Platform Atas Talian Pembelajaran Asas Fardhu Ain bagi Saudara Kita di Johor. DIm. Azri Bhari et al. (pnyt.). Potensi Muallaf Mendepani Cabara Era Kontemporari, hlm. 3750. Shah Alam: Institut Kajian Zakat (IKAZ) \& Akademi Pengajian Islam Kontemporari (ACIS).

Praditasari, W. A. A., Kholis, I., \& Budiman, A. A. (2018). Design and Implementation of the Korea Muallaf Centre Application as a Guide to Praying and Iqro' Procedure for Korean Muallaf. Journal of Physics: Conference Series, 1193:1 - 6.

Rahman, A. N. A. (2013). Dakwah sebagai Discource Budaya dan Impaknya dalam

Rahman, Mohd. Syuhaimi. Ab., Nor, Mohd. Jailani. Mohd \& Zain, Shahrom. Md.. 2017 Pemantapan Pengurusan Penyelidikan. Bangi: Penerbit UKM.

Rosli, R. (2017). Metodologi Dakwah Malaysian Chinese Muslim Association (MACMA) Kelantan Kepada Mualaf. Tesis Sarjana. Universiti Kebangsaan Malaysia.

Sah, M. A. Mat. \& Ismail, M. (2003). Status Program Pembelajaran di Kalangan Saudara Baru: Kajian Kes di Negeri Melaka. Pertanika Journal. 11: 81-95.

Salim, S. (2018). Media Roles in Islamic Conversion: A Study in Sabah, Sarawak and Brunei. Borneo Research Journal, 12: 1-19.

Suhid, A., Ahmad, A. M., Fakhruddin, F. M., \& Abah, N. C. (2019). Aplikasi 'Uruf dalam Amalan Adat dan Budaya Saudara Baharu di Malaysia: Satu Tinjauan Awal.

Yudha, A. E. P., \& Setiyowati, E. (2016). Muallaf Centre Design As An Implementation of Psychological and Economical Effect for Muallaf in Malaysia. Journal of Islamic Architecture, 4: 37-43

Yunus, A. Redzuwan, M., Don, A. G., Endot, I., Sham, F. M., Puteh, A., \& Borham, A. H. (2011). Halatuju Organisasi Dakwah Orang Asli di Negeri Pahang. Dlm. Ahmad Redzuwan Mohd Yunus \& Salasiah Hanin Hamjah (pnyt.). Pengurusan Organisasi Dakwah, hlm. 111-120. Bangi: Penerbit UKM.

Yunus, A. R. M. \& Karim, N. K. A. (2005). Pembelajaran Berkesan kepada Saudara Baru: Kajian di Darul Arqam, Singapura. Dlm. Razaleigh Muhamat@ Kawangit et al. (pnyt.). Masa Depan Saudara Baru, hlm. 9-28. Bangi: Pusat Islam UKM.

Yusri, S. F. Z., \& Abdullah, N. A. M. T. (2015). Pengajaran Pendidikan Islam Terhadap Mualaf: Satu Tinjauan Literatur. DIm. Ahmad Irdha Mokhtar \& Zulkefli Aini (pnyt.). Prosiding Seminar Pengurusan Islam: Ke Arah Pemantapan Ummah, hlm. 1-17.Bangi, Selangor.

Yusuf, N., Noor, A. M., Aziz, A., \& Bujang, S. (2019). Kepentingan Sokongan Sosial dalam Pengukuhan dan Pemantapan Akidah Golongan Muallaf. Dlm. Azri Bhari et al. (pnyt.). Dlm. Potensi Muallaf Mendepani Cabara Era Kontemporari, hlm. 97-110. Shah Alam: Institut Kajian Zakat (IKAZ) \& Akademi Pengajian Islam Kontemporari (ACIS).

Zafik, Z., \& Dakir, J. (2013). Bimbingan dan Kaunseling Mualaf di Pejabat Agama Islam Daerah Hulu Langat Selangor. DIm. Siti Ruqayah Hj. Tibek et al. (pnyt.). Prosiding Antarabangsa Pembangunan Muallaf 2013, hlm. 129-136. Shah Alam: Majlis Agama Islam: Selangor. 
Zaim, N. H., \& Kusrin, Z. M. (2014). Sokongan Terhadap Saudara Baru MenurutSyarak. DIm. Md. Yazid Ahmad et al. (pnyt.) Isu Syariah dan Undang-Undang, 20: 107-124.

Zain, A. A. M. (2015). Pengantar Dakwah Islamiah. Ed.ke-6. Kuala Lumpur: Penerbit UM.

Zain, A. M., \& Mokhtar, P (2017). Metodologi Dakwah kepada Masyarakat Orang Asli: Pengalaman Pengislaman di Sungai Berua, Hulu Terengganu. Dlm. Abdul Ghafar Don \& 